\title{
Inclusive Education is a Multi-Faceted Concept
}

DAVID MitCHELL ${ }^{1}$

$\approx$ With the impetus of the UN Convention on the Rights of People with Disabilities, inclusive education is an idea whose time has arrived around the world. Its scope goes far beyond learners with disabilities and has now been extended to cover all learners with special educational needs, whatever their origins. It also extends beyond the mere placement of such learners in regular classes to include consideration of multiple facets of education. The present paper examines a model of inclusive education that, in addition to placement, embraces vision, curriculum, assessment, teaching, acceptance, access, support, resources and leadership. For each of these facets, criteria are specified and indicators are suggested.

Keywords: inclusive education, adaptations, resources, leadership, evidence-based teaching strategies 


\section{Inkluzivno izobraževanje je večdimenzionalni koncept}

DAVID Mitchell

$\propto$ Vpliv Konvencije Združenih narodov na pravice ljudi s posebnimi potrebami je idejo inkluzivnega izobraževanja po vsem svetu postavil v ospredje. Ideja sega veliko širše kot le na področje invalidnih učencev, ker zajema vse učence s posebnimi izobraževalnimi potrebami, in to ne glede na njihov izvor. Poleg tega ideja ne vključuje samo vključevanja teh učencev $\mathrm{v}$ redne razrede, ampak tudi razmislek o različnih vidikih izobraževanja. $\mathrm{V}$ prispevku je prikazan model inkluzivnega izobraževanja ki poleg same vključitve obsega tudi vizijo, kurikulum, ocenjevanje, poučevanje, sprejetje, dostop, podporo, vire in vodenje. $\mathrm{Za}$ vsak vidik so definirana merila in predlagani kazalniki.

Ključne besede: inkluzivno izobraževanje, prilagoditve, viri, vodenje, strategije poučevanja, osnovane na podlagi dokazov 


\section{Introduction}

At its most basic, inclusive education means educating learners with special educational needs in regular education settings. This process involves the transformation of schools to cater for all children. In the present paper, I will elaborate on the notion that inclusive education (IE) is a multifaceted concept, which can be summarised in the formula IE $=\mathrm{V}+\mathrm{P}+5 \mathrm{As}+\mathrm{S}+\mathrm{R}+\mathrm{L}$, where

$\mathrm{V}=$ Vision

$\mathrm{P}=$ Placement

A = Adapted Curriculum

$\mathrm{A}=$ Adapted Assessment

A $=$ Adapted Teaching

$\mathrm{A}=$ Acceptance

$\mathrm{A}=$ Access

$\mathrm{S}=$ Support

$\mathrm{R}=$ Resources

$\mathrm{L}=$ Leadership

This is shown in Figure 1.

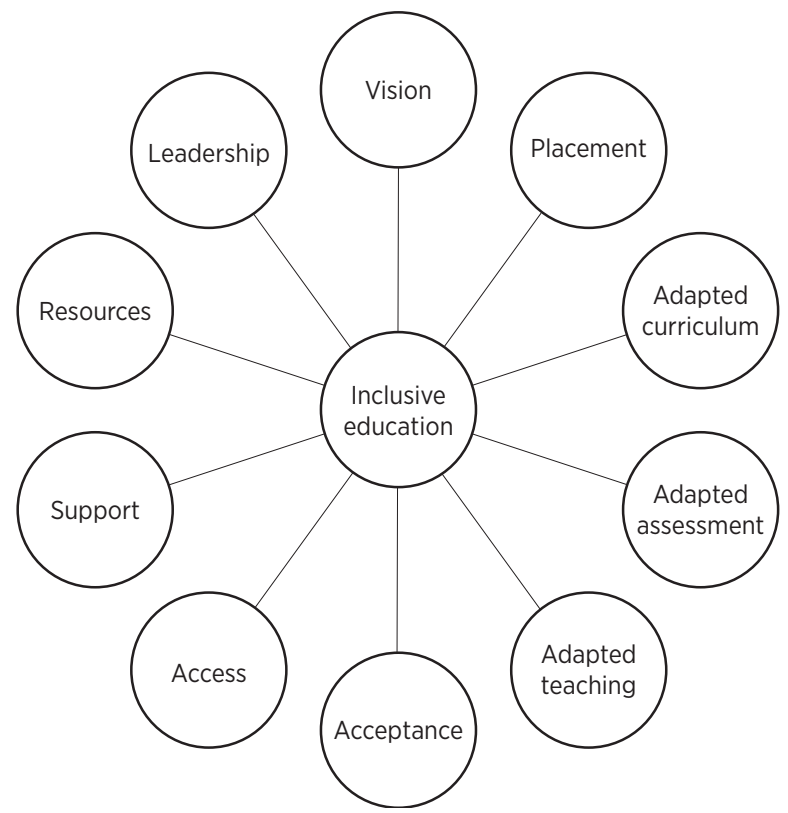

Figure 1. Model of inclusive education 


\section{Vision}

Inclusive education depends on educators at all levels of the system being committed to its underlying philosophy and being willing to implement it. This means that education systems and schools should articulate an inclusive culture in which "there is some degree of consensus ... around values of respect for difference and a commitment to offering all pupils access to learning opportunities" (Ainscow \& Miles, 2008, p. 27). It means recognising the obligations that most countries entered into when they signed and ratified the Convention on the Rights of Disabled Persons (United Nations, 2006), which includes a significant commitment to inclusive education in Article 24, stating, inter alia:

1. States Parties recognise the right of persons with disabilities to education. With a view to realising this right without discrimination and on the basis of equal opportunity, States Parties shall ensure an inclusive education system at all levels, and life-long learning, directed to: (a) The full development of the human potential and sense of dignity and self worth, and the strengthening of respect for human rights, fundamental freedoms and human diversity; (b) The development by persons with disabilities of their personality, talents and creativity, as well as their mental and physical abilities, to their fullest potential; (c) Enabling persons with disabilities to participate effectively in a free society.

2. In realising this right, States Parties shall ensure that:

(a) Persons with disabilities are not excluded from the general education system on the basis of disability, and that children with disabilities are not excluded from free and compulsory primary education, or from secondary education, on the basis of disability;

(b) Persons with disabilities can access an inclusive, quality, free primary education and secondary education on an equal basis with others in the communities in which they live;

(c) Reasonable accommodation of the individual's requirements is provided;

(d) Persons with disabilities receive the support required, within the general education system, to facilitate their effective education;

(e) Effective individualised support measures are provided in environments that maximise academic and social development, consistent with the goal of full inclusion.

\section{Criterion}

Educators at all levels of the system are committed to the underlying philosophy of inclusive education and express a vision for inclusive education in legislation, regulations and policy documents at all levels of the education system. 


\section{Indicators}

1. The principal/head teacher of the school consistently expresses a commitment to inclusive education.

2. Other senior members of the school leadership are committed to inclusive education.

3. The school's board/governing body is committed to inclusive education.

4. The national/regional/local bodies responsible for education are committed to inclusive education.

\section{Placement}

Most scholars of inclusive education either explicitly or implicitly state that inclusion refers to the placement of all students in regular schools and classrooms, regardless of their level of ability (Luciak \& Biewer, 2011). In an early meta-analysis, 11 empirical studies carried out between 1975 and 1984 were analysed. It was shown that mainstreamed disabled students (mentally retarded, learning disabled, hearing impaired and mixed exceptionalities) consistently outperformed non-mainstreamed students with comparable special education classifications. Two types of mainstreaming were included: part-time with occasional pull-out resource class attendance, and full-time inclusion in general classes. Of the 115 effect sizes calculated, two-thirds indicated an overall positive effect of mainstreaming. The overall effect size was 0.33 , which translates into a gain of 13 percentiles for students in mainstreamed settings (Wang \& Baker, 1986). In a more recent meta-analysis, Hattie (2009) obtained a somewhat more modest effect size of 0.21 in favour of mainstreaming.

A Canadian study of third-grade students with 'at risk' characteristics (e.g., learning disabilities, behaviour disorders) compared the impact of a multifaceted inclusive education programme on achievement. The intervention group $(\mathrm{N}=34)$ received all instruction and support in general education classrooms, while the comparison group $(\mathrm{N}=38)$ received 'pull-out' resource room support. Significant effects were found in the writing scores for the inclusive education group. Furthermore, the general education students were not held back by the presence of the at-risk students in the classroom; on the contrary, their reading and mathematics scores benefited from the additional interventions offered by the programme (Saint-Laurent et al., 1998).

A US study addressed the effects of an inclusive school programme on the academic achievement of students with mild or severe learning disabilities in grades 2-6. The experimental group comprised 71 learning disabled students from three inclusive education classrooms. In these classrooms, special 
education teachers worked collaboratively with general education teachers, each student's programme was built upon the general education curriculum, and instructional assistants were used to support the students. The control group of 73 learning disabled students were in classrooms in which the students received traditional resource class programmes. The results showed that the students with mild learning disabilities in the inclusive classrooms made significantly more progress in reading and comparable progress in mathematics, compared with those in the resource classes. Students with severe learning disabilities made comparable progress in reading and mathematics in both settings (Waldron \& McLeskey, 1998).

In a study carried out in Hawaii, the effects of placement in general education classrooms or in self-contained special education classrooms on the social relationships of students with severe disabilities were reported. Nine matched students were studied in each of the two placements. The results showed that those who were placed in the general education classrooms had higher levels of contact with non-disabled peers, received and provided higher levels of social support, and had much larger friendship networks (Fryxell \& Kennedy, 1995).

One of the most comprehensive studies of the effects of inclusive programmes on the development of social competence in students with severe disabilities is that reported by Fisher and Meyer (2002). In a matched-pairs design, 40 students were assessed across two years of inclusive versus self-contained special education classrooms. Those in the inclusive programme made significant, albeit small, gains on measures of social competence, compared with students in self-contained classrooms.

Finally, a Dutch study reported on the differences in academic and psychosocial development of at-risk students in special and mainstream education. It was found that those in special education classes did less well in academic performances and that these differences increased as the students got older. In psychosocial development, variables such as social behaviour and attitudes to work also favoured students in regular classes (Karsten et al., 2001).

\section{Criterion}

All learners with special education needs are educated in age-appropriate classes in their neighbourhood schools, regardless of their ability.

\section{Indicators}

1. All learners with special educational needs attend their neighbourhood school. 
2. They are placed in age-appropriate classes.

3. They are withdrawn for additional assistance no more frequently than other learners in the class.

\section{Adapted Curriculum}

Elsewhere, I have argued that making appropriate adaptations or modifications to the curriculum is central to inclusive education (Mitchell, 2014). I pointed out that such a curriculum should be a single curriculum, that is, as far as possible, accessible to all learners, including those with special educational needs. (Conversely, special educational needs are created when a curriculum is not accessible to all learners.) In addition it should include activities that are age-appropriate, but are pitched at a developmentally appropriate level. Since an inclusive classroom is likely to contain students who are functioning at two or three levels of the curriculum, this means that multi-level teaching will have to be employed; or, at a minimum, adaptations will have to be made to take account of the student diversity.

With the advent of inclusive education policies and practices, many countries are addressing the need for students with special educational needs to have access to the general education curriculum. In the US, for instance, IDEA 1997, IDEIA 2004 and the No Child Left Behind Act of 2001 specified that all students, including those with significant cognitive disabilities, must have the opportunity to participate and progress in the general curriculum. Scotland is another country that seeks to ensure that students with special educational needs can access the common curriculum framework, while at the same time ensuring appropriate and targeted support (Riddell, Tisdall, Kane, \& Mulderrig, 2006). This arrangement has been in place since the early 1990s, when the 5-14 Curriculum, with its accompanying Support for Learning pack, came into force. This material endorsed five strategies for customising the curriculum: differentiation, adaptation, enhancement, enrichment and elaboration. According to Riddell et al., these strategies would enable teachers to plan a suitable curriculum for individual students, while ensuring that their learning was framed by the national curriculum guidelines.

Several researchers have investigated ways in which IEPs can be connected with the general curriculum. For example, Fisher and Frey (2001) described a study in which students with 'significant disabilities' accessed the core curriculum in several regular classrooms. The authors concluded that, despite there being "a disconnect between the IEP and curriculum and instruction" (p. 148), "the findings... indicated that students with significant disabilities can and do access the core curriculum with appropriate accommodations and 
modifications" (p. 155). These accommodations and modifications are worth quoting at length. An accommodation is a change made to the teaching procedures in order to provide a student with access to information and to create an equal opportunity to demonstrate knowledge and skills. Accommodations do not change the instructional level, content, or performance criteria for meeting standards. Examples of accommodations include enlarging the print, providing oral versions of tests, and using calculators. A modification is a change in what a student is expected to learn and/or demonstrate. A student may be working on modified course content, but the subject area remains the same as for the rest of the class. If the decision is made to modify the curriculum, it is done in a variety of ways, for a variety of reasons, with a variety of outcomes. Again, modifications vary according to the situation, lesson or activity. The four most common ways are listed here:

- Same, only less - The assignment remains the same except that the number of items is reduced. The items selected should be representative areas of the curriculum.

- $\quad$ Streamline the curriculum - The assignment is reduced in size, breadth or focus in order to emphasise the key points.

- Same activity with infused objective - The assignment remains the same, but additional components, such as IEP objectives or skills, are incorporated. This is often done in conjunction with other accommodations and/ or modifications in order to ensure that all IEP objectives are addressed.

- Curriculum overlapping - The assignment for one class may be completed in another class. Students may experience difficulty grasping the connections between different subjects. In addition, some students work slowly and need additional time to complete assignments. This strategy is especially helpful for both of these situations (p. 157).

With particular reference to the unique needs of students with mental retardation in accessing the general curriculum, Wehmeyer et al. (2002) presented a multi-step, multi-level decision-making model. It involves three levels of action (planning, curriculum and instruction), three levels relating to the scope of instruction (whole school, partial school and individualised), and three levels of curriculum (adaptation, augmentation and alteration). At one extreme, this model suggests that some students have extensive needs for support, significant alterations to the general curriculum, and individual teaching; at the other extreme, some have only intermittent needs for support, and require minor adaptations to the general curriculum and a school-wide implementation of high quality instructional strategies. 
In recent years, writers have been advocating using the principles of Universal Design for Learning (UDL) "as a blueprint or framework for educators in designing flexible curriculum and instruction" (Brownell, Smith, Crockett, \& Griffin, 2012, p. 81).

\section{Criterion}

The standard curriculum is adapted or modified so that it suits the abilities and interests of all learners. In the case of learners with special educational needs, this means that the curriculum content is differentiated so as to be ageappropriate, but pitched at a developmentally appropriate level.

\section{Indicators}

1. The curriculum is broadly similar for all learners (i.e., there is not a separate curriculum for learners with special needs).

2. The curriculum is adapted to take account of the abilities and interests of different groups of learners.

3. The principles of Universal Design are employed in the development of curricula.

\section{Adapted Assessment}

Just as learners with special educational needs are expected to participate and progress in the general curriculum, albeit with appropriate modifications and adaptations, so, too, are they increasingly being expected to participate in a country's national or state assessment regimes. Both trends are part of the wider concern for standards-based reform in education that is dominating much of the educational and political discourse around the world.

Until recently, in the US, accountability in special education was defined in terms of progress in meeting IEP goals. That all changed in IDEA 97, which required all students, including those with disabilities, to participate in their states' accountability systems. Both IDEA 97 and the No Child Left Behind Act of 2002 required the provision of alternate assessment for students who could not participate in state or district assessments with or without accommodations. Districts are permitted to measure up to $3 \%$ of their students using alternate assessments (1\% against alternate achievement standards and $2 \%$ against modified standards).

In England, tasks and tests set for assessment at the end of Key Stages 2 and 3 (for students aged 11 and 14 , respectively) are designed to monitor attainment targets for each of the National Curriculum subjects, and are expected to be accessible to the vast majority of students, including those with special 
educational needs. However, those children in Key Stage 2 working at level 1 or below of the National Curriculum eight-level scale are assessed by teacher assessment alone. Similarly, at Key Stage 3, students working at or below level 2 of the National Curriculum scale are assessed by teacher assessment and not by statutory national testing. If a student's statement of special educational needs modifies the statutory assessment arrangements, the provisions within the statement should be followed in respect of the statutory tests and tasks. With regard to the GCSEs and GCE A levels, although the same examinations are available for students with special educational needs as for other students, special arrangements in examinations may be made for some of them. The nature of these arrangements is determined according to the assessment needs of the individual student, but must not give him or her an unfair advantage over other students. Some may be awarded extra time to complete the assessment task, or may be permitted to take supervised breaks or rest periods during the examination. For visually impaired students, the visual presentation of the papers may be changed by, for example, the use of large print or a simplified layout of the examination paper, or by the use of Braille versions of the papers. Other candidates may have questions read to them, flashcards may be used to assist hearing-impaired candidates in mental arithmetic tests, or typewritten, word-processed or transcribed responses may be accepted from students who are unable to write. Some candidates may also be allowed to take their examinations at a venue other than the examination centre, for example, at home or in hospital (see http://www.inca.org.uk/wales-sources-special.html\#31).

In the US, the National Center on Educational Outcomes has published extensively on alternate assessment for students with significant cognitive disabilities (see Lazarus, Cormier, Crone, \& Thurlow, 2010; Lazarus, Hodgson, \& Thurlow, 2010; Olson, Mead, \& Payne, 2002; and Quenemoen, Thompson, \& Thurlow, 2003). These documents provide information on States' accommodation policies on alternate assessments and guidelines for such assessments. Other useful guides to alternate assessment are to be found in the recently published book by Bolt and Roach (2009) and in publications from the US Department of Education, particularly those relating to its policy for including students with disabilities in standards-based assessment used in determining 'adequate yearly progress' (Technical Work Group on Including Students with Disabilities in Large Scale Assessments, 2006).

Basically, there are two types of adjustments to nation- or state-wide assessments.

- Assessments with accommodations. This involves making changes to the assessment process, but not to the essential content. Braden et al. (2001) 
described accommodations as alterations to the setting, timing, administration and types of responses in assessments. Here, assessors need to distinguish between accommodations necessary for students to access or express the intended learning content and the content itself.

- Alternate assessments. As defined by the US Department of Education (2003), alternate assessments are assessments "designed for the small number of students with disabilities who are unable to participate in the regular State assessment, even with appropriate accommodations" (p. 68699). They refer to materials collected under several circumstances, including: teacher observations, samples of students' work produced during regular classroom instruction, and standardised performance tasks. Furthermore, alternate assessments should have:

- a clearly defined structure,

- guidelines determining which students may participate,

- clearly defined scoring criteria and procedures,

- a report format that clearly communicates student performance in terms of the academic achievement standards defined by the State, and

- high technical quality, including validity, reliability, accessibility and objectivity, which applies to regular State assessments as well.

\section{Criterion}

The content of assessment reflects any adaptations to the curriculum. In addition, the means of assessment is adapted to take account of the abilities of all learners. Assessment of learners with special educational needs results in individual educational plans.

\section{Indicators}

1. The content of assessment tasks reflects any adaptations made to the curriculum.

2. Assessment tasks take account of the abilities of all learners; for example, a blind learner is assessed via Braille or orally, a deaf learner via sign language, etc.

3. Learners with special educational needs have individual educational plans, which form the basis of their assessment.

\section{Adapted Teaching}

Educators are increasingly expected to be responsible not only for helping students to achieve the best possible outcomes, but also for using the most 
scientifically valid methods to achieve them. Indeed, in the United States, the No Child Left Behind Act requires teachers to use "scientific, research-based programs", defined as: "(1) grounded in theory; (2) evaluated by third parties; (3) published in peer-reviewed journals; (4) sustainable; (5) replicable in schools with diverse settings; and (6) able to demonstrate evidence of effectiveness." As noted by Brownell et al. (2012), "Classroom teachers have the responsibility to provide all students with well-paced, research-based instruction" (p. 12).

In my recent book (Mitchell, 2014), I present some 27 strategies that have a substantial evidence base for improving outcomes for learners with special educational needs. Briefly, I define such strategies as having been "shown in controlled research to be effective in bringing about desired outcomes in a delineated population of learners" (p. 3 ).

For the sake of brevity, I will provide a short summary of 12 such strategies.

- Behavioural approaches. Behavioural approaches focus on how events that occur either before (antecedents) or after (consequences) learners engage in a verbal or physical act affect their subsequent behaviour.

- Functional behavioural assessment. Functional behavioural assessment is a subset of the behavioural approaches outlined above. In essence, it refers to the procedures used to determine the function or purpose of a learner's repeated undesirable behaviour and what leads to it being maintained.

- Review and practice. This requires planning and supervising opportunities for learners to encounter the same skills or concepts on several occasions. It is aimed at helping learners to 'internalise' concepts and skills once they have been initially taught. This is particularly the case with basic skills that are taught hierarchically, so that success at any level requires the application of knowledge and skills mastered earlier.

- Direct Instruction. Direct Instruction (DI) is a multi-component instructional strategy centring on teacher-directed, explicit, systematic teaching based on scripted lesson plans and frequent assessment. Research studies have consistently shown that DI has a positive effect across a range of learners and across various subject areas.

- $\quad$ Formative assessment and feedback. Formative assessment and feedback is a combined strategy in which teachers (a) probe for knowledge within lessons, (b) give frequent feedback to learners (sometimes referred to as corrective feedback), and (c) adjust their teaching strategies, where necessary, to improve learners' performances.

- Cooperative group teaching. This is based on two main ideas about learning. First, it recognises that when learners cooperate, or collaborate, 
it has a synergistic effect. In other words, by working together they can often achieve a result that is greater than the sum of their individual efforts or capabilities. Second, it recognises that a great deal of knowledge is socially constructed; that is, children learn from others in their immediate environments: their families, friendship groups and classmates.

- $\quad$ Peer tutoring. Peers play multiple roles in supporting and teaching each other, a 'natural' social relationship that teachers should capitalise on. There is a substantial literature on peer tutoring, i.e., situations in which one learner (the 'tutor') provides a learning experience for another learner (the 'tutee'), under a teacher's supervision.

- Social skills training. This is a set of strategies aimed at helping learners establish and maintain positive interactions with others. Most children quite easily acquire the social skills that are appropriate to their culture, but some do not and must be explicitly taught them. Some have poor social perception and consequently lack social skills.

- Classroom climate. The classroom climate is a multi-component strategy comprising the psychological features of the classroom, as distinct from its physical features. The key principle is to create a psychological environment that facilitates learning, thus drawing attention to three main factors: (a) relationships, (b) personal development, and (c) system maintenance.

- $\quad$ Cognitive Strategy Instruction. Cognitive Strategy Instruction (CSI) refers to ways of assisting learners to acquire cognitive skills, or strategies. It does this by helping them to (a) organise information so that its complexity is reduced, and/or (b) integrate information into their existing knowledge. It includes teaching skills such as visualisation, planning, self-regulation, memorising, analysing, predicting, making associations, using cues, and thinking about thinking (i.e., metacognition).

- $\quad$ Self-Regulated Learning. Self-Regulated Learning (SRL) aims at helping learners to define goals for themselves, to monitor their own behaviour, and to make decisions and choices of actions that lead to the achievement of their goals. Ultimately, SRL is directed and regulated by motivation. This strategy can be used in a variety of settings, across a range of subjects, and with learners with and without special educational needs. Most definitions of SRL refer not only to the regulation of cognitive processes, but also to the regulation of behaviour and emotions (Rueda, Posner, \& Rothbart, 2011).

- Memory strategies. Here, consideration must be given to ways of enhancing primary memory, short-term memory, long-term memory and the 
executive system. The principal considerations for developing memory skills include mnemonics, motivation, attention, pacing of lessons, rehearsal, transforming material into mental representations, and chunking. In addition, consideration should be given to the relationship between memory and emotions.

\section{Criterion}

As appropriate to the composition of classes and the needs of individual learners, the teaching strategies described by Mitchell (2014) are adopted.

\section{Indicators}

1. A substantial number of the classroom-focused teaching strategies outlined by Mitchell (2014) are utilised, where appropriate.

2. Teachers utilise data on learner outcomes to design and evaluate their teaching strategies.

\section{Acceptance}

The education system and the school recognise the right of learners with special educational needs to be educated in general education classrooms and to receive equitable resourcing. Acceptance is not only a matter of recognising the rights of such learners, but also, ideally, of teachers and fellow students accepting human diversity at a philosophical level and accepting individuals with special educational needs socially and emotionally.

\section{Criterion}

The education system and the school recognise the right of learners with special educational needs to be educated in general education classrooms, to receive equitable resourcing and to be accepted socially and emotionally.

\section{Indicators}

1. The school board/governing body recognises the rights of learners with special educational needs to inclusive education.

2. The national/regional/local bodies responsible for education recognise the rights of learners with special educational needs to inclusive education.

3. The principal/head teacher and other staff members recognise the rights of learners with special educational needs to inclusive education.

4. The school accepts individual learners with special educational needs socially and emotionally. 
Access

Access is a very broad concept, ranging from access to education, access to the adapted curriculum and assessment (discussed earlier), and adequate physical access to and within classrooms. The latter is provided through such features as ramps and lifts, adapted toilets, doorways that are sufficiently wide to take wheelchairs, and adequate space for wheelchairs to be manoeuvred in classrooms. Physical access also involves ensuring that all of the elements of the indoor physical environment that may affect students' ability to learn are optimal. It involves attending to such matters as the design and arrangement of furniture, acoustics, lighting, temperature, air quality and safety.

For example, it is important to arrange learners' workspaces to facilitate flexible grouping and differentiated instruction by allowing for whole-class, small-group and individual instruction. Some learners with autism may need access to personal space (Vogel, 2008); such learners need to avoid confusing large spaces, and instead require calm, ordered, low stimulus spaces, as well as safe indoor and outdoor places for withdrawal and to calm down (Department for Education and Employment, 2009). Furniture and equipment should be arranged in such a way as to manage inappropriate behaviour and to disrupt undesirable 'traffic' patterns and movement around the classroom (Council for Exceptional Children, 1997). Providing an optimal acoustic environment means attending to three interrelated factors (ASHA Working Group on Classroom Acoustics, 2005): (a) a poor signal-to-noise ratio (i.e., an educator's voice compared with background noise). For example, if a teacher's voice arrives at a learner's desk at $50 \mathrm{~dB}$ and the background noise is $55 \mathrm{~dB}$, the resulting signal to noise ratio (SNR) is -5 . This compares unfavourably with an optimum SNR of $+15 \mathrm{~dB}$ for learners with normal hearing and very unfavourably with the requirements of learners with special educational needs; (b) excessive sound reverberation (i.e., sound bounce, or echo). Technically, this is measured by 'reverberation time', which is the time between the cessation of a sound source and a measured decay of $60 \mathrm{db}$. Ideally, this should be no longer than $0.4-0.6$ of a second; and (c) high levels of ambient noise (i.e., the noises consistently present in an empty classroom). These should be no louder than 30-35 dB.

\section{Criterion}

Adequate physical access to and within classrooms is provided, with such features as ramps and lifts, adapted toilets, doorways that are sufficiently wide to take wheelchairs, and adequate space for wheelchairs to be manoeuvred in classrooms. In addition, the design and arrangement of furniture, acoustics, lighting, temperature and ventilation take account of individual learners' needs. 


\section{Indicators}

1. The school has adequate physical access features to accommodate people with physical disabilities and visual impairments, e.g., ramps, adapted toilets, adapted playground equipment, and accessible footpaths/ sidewalks.

2. Interior design includes doorways sufficiently wide to accommodate wheelchairs and desks/tables that can be adjusted to suit the needs of learners with physical disabilities.

3. Classrooms have appropriate lighting, acoustics, temperature and air quality.

\section{Support}

Educating learners with special educational needs requires collaboration between many people, in particular between several professionals and parents. Indeed, there are few areas of education that require such a high level of collaboration and teamwork. This is particularly true in inclusive education, where, ideally, general classroom teachers may work with a range of other professionals: various combinations of specialist teachers, paraprofessionals, special needs advisers, educational psychologists, therapists and other specialists, community agencies (such as welfare services, police and advocacy groups), technology consultants, and, of course, parents (Rainforth \& England, 1997). As I indicate elsewhere (Mitchell, 2014), to release the potential of collaboration, participants have to learn the skills of working as a team member for at least part of their work. For those used to working alone as a sole professional, it is a big step to develop new ways of working in which one is expected to share responsibility and expertise with other professionals in other disciplines: the 'private' becomes the 'public'; what was once implicit and unexpressed in professional practice has to become explicit and explained to others; one's autonomy may even seem to be reduced, as one has to adapt to other people's ideas and personalities. Successful collaboration depends on such factors as establishing clear goals, defining respective roles, adopting a problem-solving approach, and establishing mutual trust and respect. Those involved should be trained in the principles of collaboration.

Consideration should also be given to learners' differential needs for support. This draws attention to what is referred to as 'response to intervention' in the USA and 'graduated response' in England. Both of these approaches involve taking account of the severity of individual learners' needs, by (a) tracking the progress of all learners in a class, (b) identifying those whose performance is significantly below their peers, (c) systematically assessing the impact 
of evidence-based teaching adaptations on their achievement, and (d) adjusting the level of support accordingly (Mitchell, 2014).

\section{Criterion}

A team of professionals provides adequate and appropriate support for teachers. Ideally, this team consists of (a) a general educator, receiving advice and guidance from (b) a specialist adviser, access to (c) appropriate therapists and other professionals (e.g., psychologists, hearing advisers, social workers, physiotherapists, speech and language therapists, and occupational therapists), and (d) assistant teachers/paraprofessionals, learning support assistants or teacher aides. The composition of such teams varies according to the needs of the particular learners. Teams should receive appropriate training to carry out their responsibilities. The school should adopt a response to intervention model.

\section{Indicators}

1. Teachers have access to specialist adviser(s), appropriate therapists and other professionals (e.g., psychologists, hearing advisers, social workers, physiotherapists, speech and language therapists, and occupational therapists), and assistant teachers/paraprofessionals/teacher aides.

2. Team members receive training to engage in collaborative arrangements.

3. The school implements a response to intervention model.

\section{Resources}

Clearly, in order for the multifaceted approach to inclusive education outlined in this paper to be implemented, adequate resources must be provided. These include resources to cover the cost of buildings, equipment, transport and personnel. For the past decade or so, funding models for special education have been under review in many countries, driven by rising costs, concerns over efficiency and equity in the use of resources, and concerns about the incentives inherent in funding formulae for contra-indicated practices. Overall, per student education expenditures for those who receive special education services in the US are 1.91 times greater than expenditures for students who received no special education services (Chambers, Shkolnik, \& Pérez, 2003). This is comparable to other estimates, although Parrish (2000) cites a ratio of 2.3. For those students who receive services in inclusive education settings, I see no reason why these ratios should not also apply. While I recognise that many developing countries lack the resources to implement specialised technological strategies, viable solutions can be found. As Ainscow and Miles (2008) point 
out, these often "involve stakeholders working together to address barriers to participation and learning" (p. 31).

\section{Criterion}

Adequate and appropriate equipment and appropriate levels of staffing are provided.

\section{Indicators}

1. The national/regional/local education system makes sufficient resources available to the school for it to meet its inclusive education obligations.

2. The school board/governing body ensures that resources are delivered to the school and are utilised for the purposes for which they are intended.

3. The school managers ensure that sufficient resources (material and personnel) are available at the classroom level.

\section{Leadership}

Creating a positive school culture, or ethos, involves developing and implementing goals for the school. These goals should reflect the shared values, beliefs, attitudes, traditions and behavioural norms of its members, particularly those who are in leadership positions. Leadership should be exercised throughout an education system: by legislators, policy-makers, school governing bodies, principals and teachers. At the school level, Carrington, Bourke and Dharan (2012) determined that leadership from the school principal is "pivotal, and involves him or her understanding, believing in and enabling staff to participate" (p. 351). Similarly, Stanovich and Jordan (1998) found that the strongest predictor of effective teaching behaviour in inclusive education settings in Canada was the subjective school norm, as operationalised by principals' attitudes towards heterogeneous classrooms.

Exercising leadership means (a) developing a strong commitment to accepting and celebrating diversity, (b) developing a sensitivity to cultural issues, (c) setting high, but realistic, standards, and (d) achieving positive outcomes for the most disadvantaged. Leadership should be evidence-driven, focused on student outcomes, and based on recognition of the fact that success comes from individuals working together (Shaddock Nielsen, Giorcelli, Kilham, \& Hoffman-Rapp, 2009).

According to Heller and Firestone (1995) and Mayrowetz and Weinstein (1999), in order to bring about an inclusive school culture, the following leadership roles need to be exercised:

(a) provide and sell a vision: this involves defining the philosophy and goals of 
inclusion and promulgating them wherever possible, e.g., in school publications, talks to parents and the community, and in casual conversations;

(b) provide encouragement and recognition: this can be formal or informal, public or private, but it has the common feature of recognising those who are promoting inclusion;

(c) obtain resources: since one of the key barriers to the successful implementation of inclusion in many countries is the lack of appropriate resources, leadership has to advocate the provision of adequate resources to the school; once these are in the school, leaders should ensure that they are equitably distributed;

(d) adapt standard operating procedures: this involves recognising that since rules, regulations and requirements may have evolved without the significant presence of learners with special educational needs in the school, they may have to change; examples include the modification of curricula, textbooks and examinations that may be inappropriate for these learners;

(e) monitor improvement: it is increasingly unacceptable for leaders to simply 'do good'; it is necessary for them to demonstrate that what they are doing is having a positive impact on learners' achievements and social behaviour;

(f) deal with disturbances: since inclusive education is rarely a settled and universally agreed policy in any school, there will be an inevitable need to deal with overt and covert resistance.

\section{Criterion}

Those who are in leadership positions show a strong commitment to accepting and celebrating diversity, a sensitivity to cultural issues, and set high, but realistic, standards.

\section{Indicators}

1. The principal/head teacher of the school consistently expresses a commitment to inclusive education.

2. Other senior members of the school leadership are committed to inclusive education.

3. The school's board/governing body is committed to inclusive education.

4. The national/regional/local bodies responsible for education are committed to inclusive education. 


\section{Conclusion}

Inclusive education is a multifaceted concept that requires educators at all levels of their systems to attend to vision, placement, curriculum, assessment, teaching, acceptance, access, support, resources and leadership. It is no longer appropriate for policy-makers and researchers to define inclusive education solely, or even primarily, in terms of placement. The criteria and indicators presented in this paper can be used as a basis for planning inclusive education and for evaluating its quality.

\section{References}

Ainscow, M., \& Miles, S. (2012). Making Education for All inclusive: where next? Prospect: Quarterly Review of Comparative Education, 38(1), 15-34.

ASHA Working Group on Classroom Acoustics. (2005). Acoustics in educational settings: Technical report; and ASHA Special Interest Division 16, and Educational Audiology Association (2002).

'Appropriate school facilities for students with speech-language-hearing disorders'. Technical Report, ASHA Supplement 23.

Bolt, S. E., \& Roach, A. T. (2009). Inclusive assessment and accountability: A guide to accommodations for students with diverse needs. New York, NY: The Guilford Press.

Braden, J. P., Schroeder, J. L., \& Buckley, J. A. (2001). Secondary school reform, inclusion, and authentic assessment for youth with disabilities. Research Institute on Secondary Education Reform for Youth with Disabilities (RISER) Brief, 3 June, 2001. Madison, WI: Wisconsin Center for Education Research. ERIC Digests No. ED467477.

Brownell, M. T., Smith, S. J., Crockett, J. B., \& Griffin, C. C. (2012). Inclusive instruction: Evidencebased practices for teaching students with disabilities. New York, NY: The Guilford Press.

Carrington, S., Bourke, R., \& Dharan, V. (2012). Using the Index for Inclusion to develop inclusive school communities. In S. Carrington \& J. MacArthur (Eds.), Teaching in inclusive school communities (pp. 343-364). Milton, Qld: Wiley.

Chambers, J. G., Shkolnik, J., \& Pérez, M. (2003). Total expenditures for students with disabilities, 1999- 2000: Spending Variation by Disability. Report 5. Special Education Expenditure Project. Submitted to: United States Department of Education, Office of Special Education Programs. Council for Exceptional Children. (1997). CEC Code of Ethics and Standards of Practice. Reston, V. A.: Author.

Department for Education and Employment. (2009). Building Bulletin 102 (BB102) Designing for disabled children and children with special educational needs. London, England: Author. Fisher, D., \& Frey, N. (2001). Access to the core curriculum: Critical ingredients for student success. Remedial and Special Education, 22(3), 148-157.

Heller, M. F., \& Firestone, W. A. (1995). Who's in charge here? Sources of leadership for change in 
eight schools. Elementary School Journal, 96(1), 65-86.

Lazarus, S. S. Cormier, D. C., Crone, M., \& Thurlow, M. L. (2010). States' accommodations policies for alternate assessments based on modified academic achievement standards (AA-MAS) in 2008- 2009 (Synthesis Report 74). Minneapolis, MN: National Center on Educational Outcomes. Lazarus, S. S., Hodgson, J., \& Thurlow, M. L. (2010). States' participation guidelines for alternate assessments based on modified academic achievement standards (AA-MAS) in 2009 (Synthesis Report 75). Minneapolis, MN: National Center on Educational Outcomes.

Luciak, M., \& Biewer, G. (2011). Inclusive education in Austria: A comparative analysis. In A.

J. Artiles, E. B. Kozleski, \& F. R. Waitoller (Eds.), Inclusive education: Examining equity on five continents. (pp. 17-44). Cambridge, Mass: Harvard Education Press.

Mayrowetz, D., \& Weinstein, C. S. (1999). Sources of leadership for inclusive education. Creating schools for all children. Educational Administration Quarterly, 35(3), 423-449.

Mitchell, D. (2014). What really works in special and inclusive education: Using evidence-based teaching strategies. Second edition. Abingdon, Oxon: Routledge.

Olson, B., Mead, R., \& Payne, D. (2002). A report of a standard setting method for alternative assessments for students with significant disabilities (Synthesis Report 47). Minneapolis, MN: National Center on Educational Outcomes.

Parrish, T. B. (2000). Restructuring special education funding in New York to promote the objective of high learning standards for all students. Economics of Education Review, 19, 431-445.

Quenemoen, R., Thompson, S., \& Thurlow, M. (2003). Measuring academic achievement of students with significant cognitive disabilities: Building understanding of alternate assessment scoring criteria (Synthesis Report 50). Minneapolis, MN: National Center on Educational Outcomes. Retrieved 12 May 2010 from http://education.umn.edu/NCEO/OnlinePubs/Synthesis5o.html Rainforth, B., \& England, J. (1997). Collaboration for inclusion. Education and Treatment of Children, 20(1), 85-105.

Riddell, S., Tisdall, K., Kane, J., \& Mulderrig, J. (2006) Literature review of educational provision for pupils with additional support needs: final report to the Scottish Executive Education Department. Edinburgh: University of Edinburgh [available at http://www.creid.ed.ac.uk/publications.html] Rueda, M. R., Posner, M. I., \& Rothbart, M. K. (2011). Attentional control and self-regulation. In K. D. Vohs \& R. F. Baumeister (Eds.), Handbook of self-regulation: Research theory, and applications $\left(2^{\text {nd }}\right.$ edition) (pp. 284-299). New York, NY: Guilford Press.

Shaddock, A. J., Nielsen, A., Giorcelli, L., Kilham, C., \& Hoffman-Rapp, L. (2007). What are the critical factors in ensuring successful collaboration between mainstream teachers and teaching assistants? Report to the Australian Government Department of Education, Science and Training, Canberra.

Stanovich, P. J., \& Jordan, A. (1998). Canadian teachers' and principals' beliefs about inclusive education as predictors of effective teaching in heterogeneous classrooms. Elementary School Journal, 98(3), 221-238.

Technical Work Group on Including Students with Disabilities in Large-Scale Assessment. (2006). 
Including students with disabilities in large-scale assessment: Executive summary. Washington, DC: U.S. Department of Education. Retrieved on 16 May 2010 from http://www.osepideasthatwork.org/ toolkit/tk_lrgAssmnt_ES.asp

U.S. Department of Education. (2003). Title I - Improving the academic achievement of the disadvantaged; Final Rule, 68 Federal Registry 236 (December 9, 2003).

United Nations. (2006). Convention on the Rights of Persons with Disabilities. New York, NY: author. Vogel, C. L. (2008). Classroom design for living and learning with autism. Autism, Aspergerer's Digest, May/June.

Waldron, N. L., \& McLeskey, J. (1998). The effects of an inclusive school program on students with mild and severe learning disabilities. Exceptional Children, 64(4), 395-405.

Wehmeyer, M. L., Lance, G. D., \& Bashinski, S. (2002). Promoting access to the general curriculum for students with mental retardation: a multi-level model. Education and Training in Mental Retardation and Developmental Disabilities, 37(3), 223-234.

\section{Biographical note}

David Mitchell is an Adjunct Professor at the University of Canterbury in Christchurch, New Zealand. He has over 200 publications, mainly in the fields of special and inclusive education. He has held visiting professorships and has presented lectures, workshops and consultancies in 50 countries, many under the auspices of UNESCO. His most recent books are Contextualizing Inclusive Education (2005), What Really Works in Special and Inclusive Education, Second edition (2014), and Crises, Conflict and Disability: Ensuring Equality (2014) all published by Routledge. He is currently working on a book tentatively entitled Diversities in education: Effective ways to reach all learners (Routledge). 